\title{
Indonesia's academic readiness in facing a freer flow of skilled labour in 2015 ASEAN Economic Community (AEC) implementation
}

\author{
B.Y. Gitaharie \& L. Soelistianingsih \\ Department of Economics, Faculty of Economics and Business, Universitas Indonesia, Depok, Indonesia
}

\begin{abstract}
The ASEAN Economic Community (AEC) has been established since 2015 . One of its visions is to develop a single market and production base among the ASEAN member countries through its five pillars, one of which is freer flow of skilled labour, that is often referred to as university graduates. Because of its large population size, Indonesia is considered as a large market, yet with potential. However, the unemployment rate in Indonesia is $5.7 \%$ and the university graduate unemployment is $4.3 \%$ in 2014 . In addition to that, even before the AEC effectuation, foreign workers in Indonesia have increased in number-from 59,577 in 2009 to 68,957 in 2013 - and mostly work as professionals, advisors, consultants, managers, directors, supervisors, technicians and commissioners in agriculture, industry, trades and service sectors. Are Indonesia's university graduates ready to face the tighter competition in the labour market? Performing primary data collection, this study analyses the graduates' quality in the five major state universities in Indonesia and their readiness to compete in the regional labour market. The study finds that there is a gap between what the universities produce and what the labour market expects. The findings could contribute to the provision of a policy recommendation to the government on how to meet the future challenges in the labour market.
\end{abstract}

\section{INTRODUCTION}

The ASEAN Economic Community (AEC) has been established since 2015. One of the four visions of the regional economic integration is to develop a single market and production base among the ASEAN member countries through the five pillars of freer flow of goods, services, investment, capital, and skilled labour (Arifin et al., 2009, 15-17). Because of its large population size, Indonesia is often considered as a country with a large potential market. Of its large population (254.5 million in 2014), 125.3 million are in the labour force with $94.3 \%$ working and $5.7 \%$ unemployed. From the proportion of the unemployed, $9.1 \%$ are high school, 5.9\% are diploma, and $4.3 \%$ are university graduates.

Even before the AEC effectuation, foreign workers in Indonesia have increased in number-from 59,577 in 2009 to 68,957 in 2013 - and mostly work as professionals, advisors, consultants, managers, directors, supervisors, technicians and commissioners in agriculture, industry and trade, and service sectors. They come from China (22\%), Japan (15\%), South Korea (7\%), India (7\%), Malaysia (5\%), and the US (5\%), and are expected to increase as the AEC is implemented and the Indonesian economy grows. The freer labour inflows from foreign and neighbouring countries are mostly skilled labour and represent formal job types. This condition implies that Indonesia will have tighter competition in the labour market, particularly in the formal economic and business sectors. Is Indonesia's skilled labour, hence university graduates, ready to face the tighter competition that comes not only from local but also foreign graduates? Collecting primary data, this study describes the existing condition 
of the five major state universities in Indonesia and analyses their preparedness to compete in the regional labour market.

\section{LITERATURE REVIEW}

The AEC's implementation implies a more challenging competition in all markets, including the labour market. To produce a regionally/internationally competitive labour force, it cannot be separated from their education process, which in this case is higher education. Higher education is provided by universities whose graduates nowadays are facing tighter competition.

There is a difference between national and global competition, but both are complements (Marginson, 2006). National competition focuses on positional competition in higher education, whose focus is in granting academic titles to graduates, that in turn may provide access to social and income prestige. Providing universities can maintain their prestige, potential students will compete to be accepted and admitted into the institutions despite the tuition fees. On the contrary, higher education institutions with global competition are not only concerned with how to maintain the prestige, but also in considering their roles in the global market. The institutions must consider the possibilities of short-term student movement/ exchange, global student flows, and segmentation of global competition.

Van Damme (2001) concludes that internationalisation of higher education is characterised by: student and lecturer mobility; internationalised curriculums that focus on quality assurance, meeting minimum international standards, such as criteria of professionalism and accreditation; campus branches; agreements on institutional cooperation and network development; Mutual Recognition Arrangements (MRAs); transnational university networks; and transnational virtual delivery of higher education to eliminate geographical barriers. The most important factor in the processes of higher education internationalisation is the quality that requires higher education institutions to have a code of practice or code of conduct. Marginson (2004) adds that in a globalised environment a higher education institution should consider global, national, and local dimensions together, better known as 'glonacal'.

Levin et al. (2006) adds that to be a World-Class University (WCU), a university must provide high quality education for students and conduct productive research and community services. To meet the requirements, a higher education institution must be distinctive, in terms of providing academic freedom and facilities, funding, diversity in students and lecturers, and programmes with internationalised curriculum; and keep the instructional quality, research quality, and student quality. A WCU faces challenges in financial resources, governance and strategic planning, quality assurance, research atmosphere/environment, and political condition.

ASEAN has already prepared what is called the ASEAN University Network (AUN). The agreement among the AUN member universities is: to enhance cooperation and solidarity among professionals, academics, scientists, and students in the ASEAN region; to develop academic and professional resources in ASEAN; and to enhance information dissemination, including electronic/digital library networks, exchanging and sharing information among the academic community, policy makers, students, and other relevant users (Agreement on the Establishment of the ASEAN University Network). Invited university members of the AUN are those: known by their status as centres of excellence in priority disciplines; that have strength in academic staff quality; that have experience in regional or international programmes; and that have laboratories, libraries, and other facilities in sufficient numbers (Agreement on the Establishment of the ASEAN University Network). Recently there are 30 universities from 10 ASEAN country members (6 plus Cambodia, Laos, Myanmar, and Vietnam) that have joined the AUN membership. In the context of Indonesia, Universitas Indonesia (UI), Institut Teknologi Bandung (ITB), Universitas Gadjah Mada (UGM), and Universitas Airlangga (UA) are already AUN members (AUN Member Universities, http:// www.aunsec.org/aunmemberuniversities.php).

Students, according to Donald and Denison (2001), are the central focus in evaluating the quality of education. Several criteria are used to perceive student quality including: 
firstly, generic skills and abilities - which cover openness and flexibility in learning, independence, responsibility, being able to make analysis and synthesis, and to think critically; secondly, academic performance - which covers academic achievement during study time at the university, completing the programme promptly, and intelligence; thirdly, employment competence - which covers employability performance, ability to secure a job after graduating, and expertise; fourthly, specific skills - which covers competence in a second language and basic mathematics; lastly, academic readiness - which covers readiness from high school graduation to enter university, and readiness for general academic requirement and certain programmes.

The qualities of university graduates influence their employability and competitiveness in the labour market. Raza and Naqvi (2011) state that graduate qualities in terms of generic skills, quality, and capability can be perceived in employers, Employers are more practical as they are normally more concerned with generic skills compared to academic grades. Therefore, it is important to accommodate generic skills into the curriculum. It is also necessary to direct and challenge the lecturer's competence to meet the skills.

\section{METHODS}

The study employs primary data collected from five selected State Universities (SUs) in Indonesia-UI in Depok, Institut Pertanian Bogor (IPB) in Bogor, ITB and Universitas Padjadjaran (UNPAD) in Bandung, and UGM in Jogjakarta. All of the university samples are located in Java.

Respondents include undergraduate active students, management of the universities/ departments/undergraduate programmes, and undergraduate lecturers. The study also interviewed a few multinational companies as graduate users, and alumni who have at least five years' work experience in order to capture external perspectives. The limited samples of users and alumni should be regarded with caution as they only represent their perspectives on the questions asked. The study uses structured questionnaires and in-depth interviews, and employs SWOT analysis. The number of respondents is shown in Table 1.

As a preliminary and case study on graduate readiness to compete in the ASEAN market, samples of universities/faculties/departments/study-programmes within the SUs are selected based on the most competitive university entrance criteria, and are summarised in Table 2 below. Further research may expand the samples to include more faculties/departments/ study-programmes and employ random sampling method with, of course, larger sample size. To capture the international aspects of users, authors also interviewed multinational company users in the fields of informatics and technology, finance, and manufactures.

Table 1. Types and distribution of respondents.

\begin{tabular}{llc}
\hline & $\begin{array}{l}\text { Number of } \\
\text { respondents } \\
\text { (people) }\end{array}$ & $\begin{array}{l}\text { Percentage } \\
(\%)\end{array}$ \\
\hline Active students & 364 & 85.25 \\
Lecturers & 30 & 7.03 \\
University/ & 20 & 4.68 \\
$\quad$ Department/ & & \\
$\quad$ Programme & & 1.41 \\
$\quad$ Management & 6 & 1.64 \\
Users & 7 & $100.00 \%$ \\
Alumni & 427 & \\
Total & & \\
\hline
\end{tabular}

Source: Survey data. 
Table 2. Selected faculties/departments/programmes for interviews.

\begin{tabular}{|c|c|c|c|c|}
\hline UI & IPB & UNPAD & ITB & UGM \\
\hline $\begin{array}{l}\text { (1) School of } \\
\text { Medicine-- } \\
\text { Undergraduate } \\
\text { Programme }\end{array}$ & $\begin{array}{l}\text { (1) Faculty of } \\
\text { Human } \\
\text { Ecology- } \\
\text { Department } \\
\text { of Community } \\
\text { Nutrition }\end{array}$ & $\begin{array}{l}\text { (1) Faculty of } \\
\text { Medicine-- } \\
\text { Undergraduate } \\
\text { Programme }\end{array}$ & $\begin{array}{l}\text { (1) Faculty of } \\
\text { Mining and } \\
\text { Petroleum } \\
\text { Engineering-- } \\
\text { Petroleum } \\
\text { Engineering } \\
\text { Undergraduate } \\
\text { Programme }\end{array}$ & $\begin{array}{l}\text { (1) Faculty of } \\
\text { Social and } \\
\text { Political } \\
\text { Sciences- } \\
\text { Communication } \\
\text { Study } \\
\text { Programme }\end{array}$ \\
\hline $\begin{array}{l}\text { (2) Faculty of } \\
\text { Engineering-- } \\
\text { Department } \\
\text { of Electrical } \\
\text { Engineering }\end{array}$ & $\begin{array}{l}\text { (2) Faculty of } \\
\text { Economics and } \\
\text { Management- } \\
\text { Department of } \\
\text { Management }\end{array}$ & $\begin{array}{l}\text { (2) Faculty of } \\
\text { Dentistry- } \\
\text { Undergraduate } \\
\text { Programme }\end{array}$ & $\begin{array}{l}\text { (2) School of } \\
\text { Electrical } \\
\text { Engineering } \\
\text { and } \\
\text { Informatics }\end{array}$ & $\begin{array}{l}\text { (2) Faculty of } \\
\text { Social and } \\
\text { Political } \\
\text { Sciences- } \\
\text { International } \\
\text { Relations Study } \\
\text { Programme }\end{array}$ \\
\hline $\begin{array}{l}\text { (3) Faculty of } \\
\text { Social and } \\
\text { Political } \\
\text { Sciences- } \\
\text { Department of } \\
\text { International } \\
\text { Relations }\end{array}$ & $\begin{array}{l}\text { (3) Faculty of } \\
\text { Mathematics } \\
\text { and Natural } \\
\text { Sciences- } \\
\text { Department } \\
\text { of Computer } \\
\text { Sciences }\end{array}$ & $\begin{array}{l}\text { (3) Faculty of } \\
\text { Pharmacy- } \\
\text { Undergraduate } \\
\text { Programme }\end{array}$ & $\begin{array}{l}\text { (3) Faculty of } \\
\text { Industrial } \\
\text { Technology }\end{array}$ & $\begin{array}{l}\text { (3) Faculty of } \\
\text { Engineering- } \\
\text { Informatics } \\
\text { Engineering } \\
\text { Study } \\
\text { Programme }\end{array}$ \\
\hline
\end{tabular}

\section{RESULTS AND ANALYSIS}

This subsection discusses three issues - SU education profiles, graduate quality, and readiness to compete. Graduate competitiveness cannot be separated from the existence of the curriculum, teaching and learning process, student and lecturer quality, and international activities.

\subsection{Higher education profiles of the five SUs}

\subsubsection{Curriculum}

The selected SUs have the vision for internationalisation and have benchmarked their curriculum to some universities in the US, the Netherlands, England, Germany, France, Australia, and Japan. The management agrees that their curriculum is at par with the curriculum of other universities in ASEAN. Using the Likert scale of 5, the strengths of the SUs curriculum are shown in Table 3. To compete among ASEAN graduates, the management agrees that the curriculum should: (1) not only put a stress on hard skills but also on soft skills (57.9\%); (2) consider global and national dimensions/aspects (21.1\%); and (3) meet employment competence $(15.8 \%)$.

\subsubsection{Teaching and learning process}

Teaching and learning process is one of the most essential factors in delivering education. All subjects offered in the surveyed programmes have a syllabus that can be accessed easily as they are distributed in class $(73.3 \%)$ or made available in the school/department websites $(43.3 \%)$. Most of the lecturers (86.7\%) have included and disclosed their Expected Learning Outcomes (ELOs) on the syllabus. The syllabuses are reviewed regularly every academic year.

Around $43 \%$ of lecturers practice mixed methods of lecturing (problem-based learning, collaborative learning, experiential learning). Only some (16.7\%), who teach classes with large numbers of students, employ conventional-lecturing methods. In delivering the subjects, most of the lecturers use textbooks $(89.9 \%)$ in English. The students add that they also read articles 
Table 3. Average scores of curriculum strength.

\begin{tabular}{ll}
\hline Curriculum strength & Management \\
\hline Curriculum is at par with those of universities abroad. & 4.37 \\
Curriculum focuses on case studies. & 4.37 \\
Curriculum emphasizes on Student Centred Learning (SCL). & 4.37 \\
Curriculum is competence based. & 4.32 \\
Curriculum based on international standards. & 4.32 \\
Curriculum applies inductive methods. & 3.68 \\
\hline
\end{tabular}

Notes: 1 : Strongly disagree; 2 : Disagree; 3 : Undecided; 4: Agree; 5 : Strongly agree.

Source: Data processed.

published in international journals. This indirectly implies that students are forced to have at least passive English skills. However, in facing a tighter global competition in the labour market, course delivery in English for regular programmes has not yet become a common policy in all SUs surveyed. IPB does not have such a policy yet, but ITB does. ITB has a common policy that applies to all faculties/schools: if there is a foreign student in a class, the course should be delivered in English. All SUs, except IPB, have policies for regular undergraduate programmes to deliver courses of 6-15 credits in English. In addition to that, the SUs offer cross-faculty courses and the policy varies across SUs. Cross-faculty courses in ITB are mandatory and students are required to take cross-faculty courses for their minors of $12-18$ credits.

To support the learning process, the SUs have prepared references that are easily accessed by students, for example in the libraries and by using online systems. Some subjects use local references-modules prepared by the lecturers, textbooks in Bahasa Indonesia, and national journals. According to students, international journals are easier to access compared to national journals, because only international journals are available online.

Mid-term and final term exams are already scheduled before the academic year begins. Almost all lecturers (93.3\%) publish their final marks, but there are still $40 \%$ who do not publish their mid-term marks. In addition to that, the SUs have not had official appeal procedures. They have complaint mechanisms that vary across schools.

\subsubsection{Students}

The five SUs surveyed are among the best in the country. High school graduates vie to be admitted to one of the five SUs. Due to the limited capacity, less than $1 \%$ of high school graduates are admitted. There are several schemes for student admissions: 1) government invitation for top ranked high school students; 2) a national entrance test to SUs; and 3) an individual university entrance test. Admitted students to these five SUs are definitely among the best high school graduates in Indonesia.

Referring to Donald and Denison (2001), student quality is not only determined by Grade Point Average (GPA) but also by other skills and abilities, one of which is student participation in research. Most lecturers (93\%) involve students in their research. However, they do not take GPA as the main consideration in recruiting students, but are more concerned in students' integrity, work ethics, teamworking ability, and English skills. Some students have their English test (TOEFL) scores ranging from 451-500. However, this score is relatively lower than that is expected by users who are facing the AEC, which is 550 .

\subsubsection{Lecturers}

Most of the faculty members or lecturers have master or doctoral degrees. Most of them are permanent lecturers and obtained their degrees abroad. Around $80-90 \%$ of them have had teaching certificates from the Ministry of Research Technology and Higher Education and other relevant certificates - some issued by international institutions. They also participate in trainings/workshops organised by the university to improve their capacity in certain areas.

Lecturers have also developed and maintained networks and collaboration in research, teaching, and community engagement. More than half of the lecturers $(60 \%)$ have organised 
joint research with European, Asian, and Australian universities/research institutes, and participate $(83 \%)$ in seminars/workshops/trainings in those countries and also the US.

\subsubsection{Internationalisation}

Lecturer/student mobility is one indicator for internationalisation and is assessed by international accreditations and AUN. The advantages of such mobility are to create, develop, and maintain networks and joint academic activities, to broaden students'/lecturers' insights of knowledge development and dissemination, and to improve students/lecturers in their academic performance in order to be acknowledged internationally/regionally. In the last five years, lecturers in the SUs have participated in lecturer mobility, mostly to ASEAN countries, Europe, Australia, and the US. Student mobility is even more in numbers. Students go for exchange to Japan, South Korea, Hungary, the Netherlands, and Austria. This exchange activity gives significant added values as students learn about other countries' cultures, academic atmosphere, study/work ethics, and they become more confident. Students spend around one month to one year for the exchanges.

Some programmes in the SUs have international students, mostly from Asian countries. As an example, UNPAD Faculty of Medicine has one special class for students from Malaysia where they use English to communicate in the class. However, they use mixed languageBahasa Indonesia and English with their local peers. Their presence in UNPAD adds somewhat to the international exposure for local students, at least in terms of language and interactions.

From the interviews with students, not more than $12 \%$ of the students participate in international seminars/conference, workshop/training, and competition. Most of the activities take place in Asia (Thailand, Hong Kong, Japan, South Korea, Malaysia, Singapore, and Taiwan), Europe (Austria, the Netherlands, Denmark, Hungary, England, German, Norway, and France), the US, and Australia. Some also participate in summer schools abroad and cultural missions.

\subsection{Graduate quality}

The survey also asked users about employment competence. According to users, graduates must have soft skills and capabilities $(66.7 \%)$, work performance $(14.3 \%)$ and specific skill $(14.3 \%)$. Employers consider more on accountability $(50 \%)$, openness and flexibility in learning something new $(33.3 \%)$, and professionalism (16.7\%), and not just academic performance. Employers also consider leadership skills (33.3\%), ability to work in groups $(33.3 \%)$, and willingness to accept challenges $(33.3 \%)$. Mastering good communication $(83.3 \%)$, foreign language $(16.7 \%)$, and basic maths $(16.7 \%)$ are also valuable. In a globalised and borderless labour market, good oral communication and foreign language skill, other than English, become very important. Basic maths skills support graduates in logical and systematic thinking that will assist them in making decisions. Users agree that SU graduates have sufficient knowledge and capabilities for problem-solving, but are lacking in good communication skills in English.

Another indicator of student quality is how fast a graduate gets a job after he/she finishes school. Based on the interview with the school/department/programme management of each $\mathrm{SU}$, it only takes three to six months to get a job after he/she graduates. Some take less than three months. This implies that SU graduates are in high demand in the labour market, particularly those from UI School of Medicine and ITB Faculty of Mining and Petroleum Engineering. According to the school/department/programme management and the lecturers, their graduates have broad knowledge, are able to adapt quickly to new circumstances, including new cultures, and know how to apply their knowledge; but they lack ability in foreign languages other than English.

In order to compete in the ASEAN labour market, graduates should have the skills of communication, presentation, and basic computer applications. Graduates, according to respondents, must be able to work together in groups and have loyalty, persistence and commitment, and good professional work ethics. International certificates on professions are additional values for graduates. Graduates should also have some basic knowledge on: Informatics, Computers, and Technology (ICT); communication; maths; community and cultures; macroeconomics; marketing; and international law in order to compete internationally. 


\subsection{Readiness to compete}

Lecturers are confident that their graduates are ready to compete both in domestic and regional labour markets. However, graduates need to improve their English skills and broaden their horizons to compete in the international market. From the students' perspectives, they $(91 \%)$ are ready to compete in the domestic labour market, but more than half of them $(62 \%)$ are not confident to compete in the international labour market, realising their shortcomings in English language skills. Some of the students (32.1\%) have had certificates in certain fields that give additional value to compete in the market. They also agree that in order to compete graduates should have good communication skills $(98.6 \%)$, knowledge on information and communication technology $(96.7 \%)$, and knowledge on community and cultures $(85.4 \%)$.

According to alumni and users, graduates are ready to compete in the domestic market, but not in regional or international markets. The main constraint is insufficient English and other soft skills. They are not prepared to face regional/international labour market competition yet. Based on alumni experience, the infrastructures in the SUs are not adequate to support the requirements for competition. Alumni also add that graduates are very good with textbook-knowledge but lack practice and creativity. They also admit the superior quality of lecturers, but their delivery method is quite monotonous. Practical experiences and solving cases should be enhanced and improved. According to users, graduates need to be equipped with the ability to communicate effectively and to make active and positive arguments. Graduates should know how to put themselves in their position.

Table 4. SWOT summaries.

\begin{tabular}{|c|c|c|c|}
\hline Strength & Weaknesses & Opportunity & Threats \\
\hline SUs have: & Graduates: & $\begin{array}{l}\text { AEC provides larger job } \\
\text { opportunity in the } \\
\text { regional market. } \\
\text { Local SU graduates have } \\
\text { higher comparative } \\
\text { advantage in knowing } \\
\text { Indonesia than foreign } \\
\text { graduates. }\end{array}$ & $\begin{array}{l}\text { Tighter competition } \\
\text { in labour market, } \\
\text { particularly } \\
\text { with graduates } \\
\text { from Singapore, } \\
\text { Malaysia, and } \\
\text { the Philippines. }\end{array}$ \\
\hline Strong curriculum & Lack English and & & \\
\hline $\begin{array}{l}\text { Excellent intake } \\
\text { student quality }\end{array}$ & $\begin{array}{l}\text { interpersonal skills } \\
\text { Lack self-esteem }\end{array}$ & & \\
\hline $\begin{array}{l}\text { Wide networks } \\
\text { with universities } \\
\text { abroad }\end{array}$ & $\begin{array}{l}\text { Lack argument skills } \\
\text { Low survival skills when } \\
\text { stationed in outer java } \\
\text { Lack necessary soft skills for } \\
\text { international exposures }\end{array}$ & & \\
\hline Graduates have: & $\begin{array}{l}\text { SUs have insufficient } \\
\text { infrastructures to } \\
\text { support learning process }\end{array}$ & & \\
\hline $\begin{array}{l}\text { Superior theoretical } \\
\text { knowledge and } \\
\text { academic performance }\end{array}$ & & & \\
\hline $\begin{array}{l}\text { Strong quantitative and } \\
\text { analytic capabilities }\end{array}$ & & & \\
\hline $\begin{array}{l}\text { Good work ethics, work } \\
\text { discipline, and are } \\
\text { independent }\end{array}$ & & & \\
\hline $\begin{array}{l}\text { Ability to quickly adapt } \\
\text { to new circumstances } \\
\text { and are fast learners }\end{array}$ & & & \\
\hline
\end{tabular}

Source: Processed from in-depth interviews. 
Table 4 summarises the results of in-depth-interviews in the form of a SWOT matrix, from which we can derive a strategic policy recommendation.

\section{CONCLUSION AND POLICY RECOMMENDATION}

This study concludes that there is a gap between the perspectives of graduates from the five SU graduates and those of users. SU graduates have excellent academic performance, strong knowledge in their relevant fields, and are ready to compete in regional labour market. Their main constraint is in the ability to communicate in English. In addition to that, users also endorse that graduates should have adequate generic and specific skills and meet employment competence. The study draws up some recommendations to meet the AEC challenges:

1. Graduate competence should include both hard and soft skills. Foreign language, particularly English, and basic computer skills must be considered as hard skills and improved significantly. Delivering hard skills should be conducted innovatively and attractively rather than in conventional ways. Improving soft skills should include oral communication and presentation skills, making objective argumentation and expressing ideas, negotiating, and networking. This will increase graduates' self-esteem in facing tighter competition in the labour market.

2. To improve human resource, lecturers are endorsed to pursue their doctoral degree and to participate more in international exposures and activities, for example to participate in international conferences as speakers/presenters and to take part in lecture mobility.

3. Universities should improve their infrastructures. Laboratories should be furnished with modern equipment. For that purpose, universities should expand networks and collaboration with relevant industries.

\section{ACKNOWLEDGEMENTS}

The authors would like to express their gratitude to the Directorate of Higher Education, Ministry of National Education, for granting the 2011 National Strategy Grants, high appreciation to Ms. Metri Sriwati for her full assistance in every stage of the research and Mr. Sulistiadi Dono Iskandar for his assistance in the survey to the five SUs.

\section{REFERENCES}

Agreement on the Establishment of the ASEAN University Network. https://web.archive.org/ web/20080704150447/http://www.aseansec.org/9621.htm Retrieved on 21 October 2016 at 15:12. AUN Member Universities. Retrieved on 21 October 2016 at 15:25 http://www.aunsec.org/aunmemberuniversities.php

Arifin, S., Djaafara, R.A. \& Budiman, A.S. (2009). 2015 ASEAN Economic Community (AEC): Strengthening ASEAN synergy in the midst of global competition (Masyarakat ekonomi ASEAN 2015: Memperkuat sinergi asean di tengah kompetisi global). Jakarta: PT. Elex Media Komputindo.

Donald, J.G. \& Denison, D.B. (2001). Quality assessment of university students. Journal of Higher Education, 72(4), 478-502.

Levin, H.M., Jeong, D.W. \& Ou, D. (2006). What is a world class university? Paper presented on The 2006 Conference of the Comparative and International Education Society, Honolulu, Hawaii. www. tc.columbia.edu/centers/coce/pdf_files/c12.pdf

Marginson, S. (2004). Competition and markets in higher education: A glonacal analysis. Policy Futures in Education, 2(2).

Marginson, S. (2006). Dynamics of national and global competition in higher education. Higher Education, 52(1), 1-39.

Raza, S.A. \& Naqvi, S.A. (2011). Quality of Pakistani university graduates as perceived by employers: Implications for faculty development. Journal of Quality and Technology Management, VII(1), 57-72. van Damme, D. (2001). Quality Issues in the Internationalization of Higher Education. Higher Education, 41(4), 415-441. 